\title{
$5 \cdot 6$ 歳万う幼児の遊戯集団に試久た害験的研究
}

\author{
一集団最上位に位する者」について一
}

\author{
東京教育大学
}

小 小再治

\section{I 問 題}

この実験は 1952 年から 4 年間にわたって, 折に触れ て行なって来たものである.筆者は 1952 年に, 東京都 の数校のろ 万学校の $5 \cdot 6$ 藏生徒が形成する, 遊戲集団 を観察した.これらの遊戯集団には，仲間の意図に対して 自分の意図を優先して貫徹する，少数の生徒がいるよ5 に思われた・このような生徒は,力の関係では集団の上位 にあるが,「リーダー」とはいえない. 何故なら, 仲間の 目標設定を助けたり，この方向に向って仲間を指導した りするような行動を，ほとんど示さないからである。

(Stogdill (1), Cattell (2), Gibb (3), Redl (4), 中村 (5) の「リーダーシップ」の定義参照). このよう な, 集団上位に市りながらリーダーシップを示さず, 自己 の意図を他に優先して通そうとする傾向の強い児童，す なわち「集団最上位に位するが，必ずしるリーダーでは ない者」には，なだ学問的な名称が与えられていないよ らである・本稿では,仮に「集団上位者」と名づける。こ れらろら児の「集団上位者」には，集団の仲間の意図を 無視する行動や，情緒的で攻撃的な行動が多いようで あった。

ところが，2・3 の保育園て，同年令正常巟の遊戯集 団を観察して見ると, 彼らの集団の上位の者はろう児の それと比べると，仲間の意困をある程度尊重する傾向が 見えた。そして仲間を目標に向って指導するような行動 も時々観察され, ある程度リーダーとしての機能を果し ているらしかった・しかしこれは, 条件に手を加えない遊 びの事態で気づいたといらにとどまり，これだけでは上 述の傾向の存在を断定できない，筆者はこのような事の 存否を明らかにし, し存在するのであれば, その 発生原因を考究する目的で, 実験・観察をこころみた。

\section{II 予備的手続き}

対象は,「遊びの事態に和沙る集団の最上位の者」に 限定した。また，「集団上位者」を一応,「数名以上の集団 で,上下の関係では集団内の最上位にあり,その集団の中 で最も自分の意図を通し得る立場にある者」と定義し た. 万弓学校は 1 学級数名加ら成っているから, 各学級
で最も上位にある生徒は，この定義に該当する，正常児 の場合はクラスの人数が多いから, クラス名簿の中から 無作為的に数名を抽出し, この数名を 1 つの集団とし て、これらの各集団から1名ずつ「集団上位者」を選出 した・ろら児の集団は学級と一致し,すでに固定してい るのに反し，正常児の集団は新しく編成されたもので， メンバーの地位がやや固定してい放い点に, 条件の差異 が認められる. しかし正常児 1 クラスの約 20 名の幼児 は, 保育園内の日常生活に拈いて相互に密接に交涉し 合って括り，クラス単位で活動している．新編成小集団 は同じクラスの者から成っているから，相互の親密性の 程度では，万弓児集団にそれ汪どは劣っていないと考え る.な拈，正常児群には特に「集団上位者」を選出で きなかった集団も $2 \cdot 3$ 存在した。

$\mathrm{Vp}$ は, 万弓児が, 東京教育大学教育学部付属乃 5 学 校生徒を主体とし，これに私立日本襲話学校生徒子若干 加わっている．正常児は東京都杉並保育園児と市川市国 府台保育園児・それぞれの施設の孤立した一室を実験室 とした。次の $\mathrm{a} ＼textrm{b}$ の 2 つの手続の双方に該当する者を 「集団上位者」と認定した.

（a）担任教官または保母が，その集団内の最上位 の者とみなした者.

(b) 1 集団の内から，2名ずつの組合せで 1 組 5 分 ずつ，別室で若干の遊具で自由遊びをやらせる・そし て一対比較法のやり方で，集団内の 2 名ずつのすべて の組合せについて行い，5分間にどちらのVp がより 多く意図を貫徹したかを，20秒単位で区切って記録す る. そしてこの 2 名の上下の序列を決定する. 最後に 全部の組合せの結果から，集団内の上下の才の関係 の，一種のソシオグラムを作る.（これの具体的作成 手続きについては, 文献 (6) に述べた。) このソシオ グラムの最高位になった者.

ろら児・正常児から選んだ「集団上位者」を対象にし て, 実験を行なった。予備実験の結果はすでに発表し た(6).この実験では,*ろうの「集団上位者」が，仲間

*この論文では, 今回の「集団上位者」を「意図貫 徹者」と名づけていた。 
に先んじて自分の意図を通し得る主要原因が，「仲間に 比しての体力の優越」ではないことが結論された。 その ため以後の実験では,「体力」以外の諸要因について, 考察を加えた。

\section{III 実験むよび考察}

以下行なった実験の内, 約半分は, Parten, etc. (7) の Social Participation Scale (社会参与尺度) 飞上る評 定を行なった。この Scale の評定項目款よび, 各項目 に与えられている得点は, 次のごとくである.

$\begin{cases}\text { 添んやりしている行動 } & -3 \\ \text { 傍観的行動 } & -2 \\ \text { 独り遊び } & -1 \\ \text { 平行遊び } & +1 \\ \text { 連合遊び } & +2 \\ \text { 協力的・組織的遊び } & +3\end{cases}$

Parten は, 観察時間中に Vp 飞現われた, 各評定項 目の回数を基準にして, 数量的処置を行なっている. 筆 者は回数よりも, 各項目の出現時間の長さを重視し,こ れを基にして処置を行なった。*

まず,「集団上位者」 1 名,「仲間」 3 名, 計 4 名から 成る集団を幾つか作った。この集団は主としてっこの Parten のScale を用いた実験に使用した。ろう児・正 常児とも、1 つの集団のメンバーは同じクラスから選ん だ・前述のようにろう学校のクラスの人数は 10 名以下 であるため, 正常児よりもクラス内の各児童の関係は, 多少固定的と思われる，そのため，集団を作ってすぐ本 実験にかかるなら，万弓児・正常児の4名の集団の性格 は多少異質的になっている可能性がある. しかし, 筆者 は最初の 3 日間は，万弓児和よび正常児の集団に別の実 験（予備実験）を行ない，毎日20 分間は 4 名一緒に遊ば せたため,この実験開始当時には，正常児の集団におい、 てもメンバーの地位はかなり固定的となっていた。この 点でのろろ児群との差買は, 一応問題にしなくてよいと 考光られる.

次に，Parten の Scale を用いた実験の施行方法につ いて述べる.上述の 4 名の集団を 1 つずつ実験室で自由 に遊ばせ，観察記録した・観察は筆者之補助者の 2 名で 同時に行ない, 各自が Vp 2 名ずつを分担記録した。**以 上の方法を講じて，この種の実験につきまとう「主観の 混入」を最小限に抑光, 条件を整一にする上らに努め た.

*「回数」,「長さ」の重要度を検討する実験を別に 行なったところ，「長さ」の方が重要であること が結論ら゙けられた。

** 補助者は当時の東京教育大生 阪田隆氏また注心 理学尃攻村岡千鶴子氏飞低頼した。予め練習を行 ない,両氏とる筆者の観察結果との相関は +.90 に達していた。
1 集団の観察時間は, 前半後半各 5 分, 合計 10 分 である、隔離観察室の設備がないため, 観察者 2 名は $\mathrm{Vp}$ と同室して記録した。使用玩具は次の 4 種. (1) 積木 1 箱 (約 40 片). (2) 煙突より火の粉を吐く機関 車 1 台. (3) 自動車玩具 2 台（木慗新上び金属性）.

(4) 縫いぐるみ人形 1 箇.

前半は 4 名全員で遊ばせる. 後半は「集团上位者」だ けを退室させ，「仲間」 3 人で遊びを続けさせる。各 $V_{p}$ の観察時間を 20 秒ごとに区切り, 各 20 秒の期間中に $\mathrm{Vp}$ が, 6 種の評定項目の内のぞれを示したか妾記入し ていく. 20 秒内に 2 種以上の評定項目が現われた場合 は、より長時間と判断された方の項目だけを記入する. そして前半・後半の各ふについて, Social Participation Scale Kよって, 集団全員の平均得点を求める. この得 点は, 下の式に上って求める.

$$
\begin{aligned}
& \text { 全員の各 } 20 \text { 秒単位時間内の } \\
& \text { 集団の平均得点 }=\frac{\text { 評定值の合計 }}{\text { 全員の } 20 \text { 秒単位時間数の合計 }}
\end{aligned}
$$

実験 1 Social Participation Scaleを用い た最も基本的な実験.

万弓児群・正常児群とも, 前半は「集团上位者」を加 光た 4 名で, 後半はこれを除いた 3 名で遊ばせ, 前半・ 後半の平均得点を求めた。 万丂児 7 集団, 正常児 8 集団 に施行した. 万弓児群・正常児群とも, 女子の「集団上 位者」はそれぞれ2名ずつで他は男子. 結果学 Table 1 汇示守。

\begin{tabular}{|c|c|c|c|c|c|}
\hline & \multicolumn{2}{|l|}{ 前 } & \multicolumn{2}{|l|}{ 後 } & \multirow{2}{*}{$\begin{array}{l}\text { 前半 } \\
\text { 後半の } \\
\text { 差 }\end{array}$} \\
\hline & $\mathrm{AV}$ & $\mathrm{SD}$ & $\mathrm{AV}$ & $\mathrm{SD}$ & \\
\hline ろら児群 & -0.9 & 0.74 & +0.7 & 0.78 & 0 \\
\hline 正常児群 & +1.2 & 0.62 & +0.2 & 0.62 & $x$ \\
\hline 両群の差 & 0 & & $x$ & & \\
\hline
\end{tabular}

Table 1 実験 1 の結果

前半はろ万児群が大体平均して「独り遊び」の段階に めるのに対し, 正常児群は「平行遊び」の段階にあり, 両群の平均值の間には有意差がある。正常児群の方がろ う児群より集団が京とまって扣り, 遊びの程度もやや高 い.ところが，「集団上位者」を除いた後半では，万弓児 群は+1の近くまで上昇するが, 逆佂正常児群は前半よ り下降している.特にろろ児群は, 前半・後半の間に有 意差を生じている・正常児群の「集団上位者」は集団の

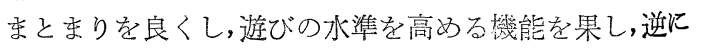
万弓坚群のそれは集団のまとまりを低下させ，遊びの水 準を低下させる機能を果したと考えられる. (正常児の場 
合, 前半・後半の間に有意差がないことは，上の仮説設 立の根拠恣やや弱くするが.)

な乱，この実験よりは多少施行条件が厳密性を欠いて いたが，東京都立のろろ学校 2 校で，同年令「集団上位 者】12 名に同じ実験を行なったところ, 結果の本質的傾 向は, Table 1 のろう児群と共通していた：(この実験つ 結果は, 昭和 28 年度心理学会で発表した。) 上述の傾 向は，5・6 才万5児にかなり一般的なるの之想像され る。

实 驗 2 Social Participation Scale 在便用.

実験 1 と同じ「集団上位者」を，1名ずつそれぞれ 4 才児 3 名と同室で遊ばせた。他の条件・方法は実験 1 と同じ。結果丟 Table 2 に示すす.

Table 2 実験 2 の結果

\begin{tabular}{|c|c|c|c|c|c|}
\hline & \multicolumn{2}{|l|}{ 前 } & \multicolumn{2}{|l|}{ 後 } & \multirow{2}{*}{$\begin{array}{l}\text { 前半. } \\
\text { 後半の } \\
\text { 差 }\end{array}$} \\
\hline & $\mathrm{AV}$ & $\mathrm{SD}$ & $\mathrm{AV}$ & $\mathrm{SD}$ & \\
\hline ろら兒群 & -1.4 & 0.91 & -0.7 & 0.88 & $x$ \\
\hline 正常睍群 & +0.6 & 0.81 & -1.0 & 1.43 & $\bigcirc$ \\
\hline 両群の差 & 0 & & $x$ & & \\
\hline
\end{tabular}

全般的に実験 1 よりも平均值が低下しているが，これ は平均等令が少いことが決定的原因と思われる。（京た， 実験 1 に比べれば，ろろ児群・正常児群とも，メンバー の位置がより不安定な集団で, 実験 1 の集时よりる, メ ソバー同志のチェックのし岕いがより多かった可能性は

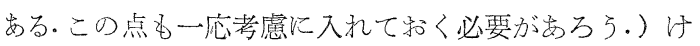
れども結果の全般的傾向は, 実験 1 と共通している。す なわら, 正常児「集団上位者」は，自分より年少肾童の 集団の委々屯りを高め, 逆にろ弓児のそれは, 年少児の 集団のまとまりを低下させることが示されている・実験 1 . 2 の結果は, 万弓児の「集団上位者」が，同年令児・ 年少児のどちらの集団に対しても，「秩序破り」として の機能を果しているのではないかという問題を提示す る.以後の実験では，この間題に対し追求を試みた。

\section{実 駼 3 および 4 Social Participation Scale} を使用しない。

実 鈳 3 「集団上位者」 1 名, 同年令児 4 名, 計 5 名で自由に遊ばせ，「集団上位者」が仲間の玩具を奪 うのを待つ. そして, この場合の玩具を奪わ机た 1 名 の $\mathrm{Vp}$ の反応行動や表情を記録する. 他の 3 名の仲間 は記録しない。柘,「集団上位者」以外の者の「奪取
行為」も記録に入れない。この「玩具奪取行為」の内に は, 「腕力に上る奪取」, 「言葉で欲求を述べてからの奪 取」等, 奪取行為はすべて含めた。正常览・ろう児の各 各につき, 1 集団 5 分ずつ, 合計 4 集团ずつ観察した。な お，今回の「集団上位者」は，両群ともすべて男である。 ろろ児群 14 回, 正常児群 5 回の「集団上位者」によ る「奪取行為」が発生した。仲間の反応は Table 3 のご とくで岁った。

Table 3 実験 3 の結果

\begin{tabular}{|c|c|c|c|c|c|}
\hline & 例 & 仲 & の & 反 & 応 \\
\hline & 数 & $\left|\begin{array}{l}\text { (イ) 肉 } \\
\text { 体的反摮 }\end{array}\right|$ & $\mid \begin{array}{l}(\text { ロ } \quad \text { ニュ } \\
=\text { ケーション } \\
\text { による抗議 }\end{array}$ & $\mid \begin{array}{lr}\text { (八) } & \text { 不 } \\
\text { 服の表情|} \mid\end{array}$ & $\begin{array}{l}(二) \\
\text { 無 表 情 }\end{array}$ \\
\hline ろう览群 & 14 & 2 & 0 & 2 & 10 \\
\hline 正常少群 & 5 & 0 & 4 & 1 & 0 \\
\hline
\end{tabular}

（（二）の判別に当っては，（八）の方を厳格に し, 筆者・補助者が共に（ハ）と認めた場合だけをと り，他は（二）に入れた。）

正常児には（口）が多い（例.「ズルイゾテメエ」， 「カエ七ヨ」等.）ところが，万弓児は口話・手香小等の 手段による抗議を1回も行なわず，大半の者は無表情の ま禁，服従してし末う。

（イ）は正常児には 1 回もないが，万弓児には 2 回現 われた。これは怒が爆発し，頭脳がまひして思考力を失 い，「集団上位者」を攻撃すれば強い反撃を受けるとい うことも見通せなくなって, 衝動的に攻撃する現象のよ うであった・正常児にこのような「近道反応」が現われ なかった大きな原因は、コミニニケーションによる間接 的折衝が，ろら児より子容易で女ることに帰し得ると

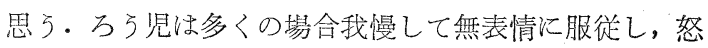
が爆発すれば衝動的に反撃するという，两極端の行動が 現われ易いようである。

实 験 4 Table 3 のろ万児群（二）の10 回のケ一 スで, 無表情に服従したろう児が, 心理的に不満感を るっていたか，岁るいは相手の玩具奪取を当然のことと して心理的に緊張しなかったかを検討するためる5児 だけを詨象にして行なった。「集団上位者」1名「仲間」 1 名, 計 2 名の集団を 9 つ作った. 各集団を各々 5 分 ずつ遊ば也，「䉘団上位者」が玩具奪取を試みるのを待っ

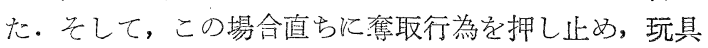
を仲間に返してやり，仲間のろう児の表情を観察した。 この行為は内 7 集団に 1 回ずつ, 計 7 回発生したが, 7 人の内 6 人の仲間は，筆者が玩具を返してやった時に， 笑いの表情を示した。この笑いは, 喜悦の現われと推測 され, 要求充足による満足感淿由来すると解釈された. （他の 1 名は预びえた表情で玩具を受取らなかった。）こ 
の結果から推測すると,ろう児が「集団上位者」の「秩 序破り」に無表情に服従する場合でも，心理的に不満を 感じフラストレートしていることが多いと思われる。

実験 5 および 6 いろいろな程度の「秩序破 り」の行為と, 仲間の反応との関係について,さらに検 討した。

実 験 5 実験 3 .4 のような自然観察法では，い ろいろな種類の「秩序破り行為」の充分な例数が得られ ないので, 筆者の方であらかじめ定めた「秩序破り行為」 を，非教育的効果を生じないような配虑の下に，1 人の 成人（女子）に行なわせ，Vp の反応を見た。 （(a)一（e）はなるべく自然的に，括だやかな態度で やって鿓った。）この実臨は，「秩序破り」の者が成人で あるから，今回考察の対象にしていない，いろいろの要 因が影響して来る。乙かし同年令の幼児に，計画的に 「秩序破り」をやらせることは出来ないから，やむを得 なかった・ろ弓児群 9 集団に，また正常児群には延べ 12力月にわたり 30 集団に施行した. Vp の反応は, 直 接に「秩序破りの行為」の被害を受けている1名だけに ついて記録した。結果を Table 4 括よび 5 に示す。

実 駿 6 Table 4 のろう児群 (二) (e) の4名 について, 実験 4 と同様に，筆者が成人から玩具を取

Table 4 実験 5 の結果

\begin{tabular}{|c|c|c|c|c|c|c|c|c|c|}
\hline \multirow[t]{2}{*}{$\mathrm{Vp}$} & \multirow[t]{2}{*}{$\begin{array}{|cc|}\text { 反 } & \text { 応 } \\
\text { 行 } & \text { 為 } \\
\end{array}$} & \multicolumn{2}{|c|}{ （イ）肉体的反摮 } & \multicolumn{2}{|c|}{$\begin{array}{l}\text { (ロ) コミュニケー } \\
\text { ションによる抗議 }\end{array}$} & \multicolumn{2}{|c|}{ （八）不服の表情 } & \multicolumn{2}{|c|}{ （二）無 表 情 } \\
\hline & & 数 & $\%$ & 数 & $\%$ & 数 & $\%$ & 数 & $\%$ \\
\hline \multirow{5}{*}{$\begin{array}{l}\text { 万 } \\
5 \\
\text { 児 } \\
\text { 群 }\end{array}$} & a & 0 & (0) & 0 & $(0)$ & 1 & $(11.1)$ & 8 & $(88.8)$ \\
\hline & $b$ & 0 & $(0)$ & 0 & $(0)$ & 1 & $(11.1)$ & 8 & $(88.8)$ \\
\hline & c & 0 & (0) & 0 & $(0)$ & 3 & $(33.3)$ & 6 & $(66.6)$ \\
\hline & d & 0 & $(0)$ & 0 & $(0)$ & 3 & $(33.3)$ & 6 & $(66.6)$ \\
\hline & $\mathrm{e}$ & 0 & (0) & 0 & $(0)$ & 5 & $(55.5)$ & 4 & $(44.4)$ \\
\hline \multirow{2}{*}{ 正 } & a & 0 & $(0)$ & 3 & $(10.0)$ & 6 & $(20.0)$ & 21 & $(70.0)$ \\
\hline & b & 0 & $(0)$ & 7 & $(23.3)$ & 10 & $(33.3)$ & 13 & $(43.3)$ \\
\hline \multirow{2}{*}{$\begin{array}{l}\text { 常 } \\
\text { 児 }\end{array}$} & c & 0 & $(0)$ & 6 & $(20.0)$ & 12 & $(40.0)$ & 12 & $(40.0)$ \\
\hline & $\mathrm{d}$ & 0 & $(0)$ & 12 & $(40.0)$ & 13 & $(43.0)$ & 5 & $(16.6)$ \\
\hline 群 & e & 0 & $(0)$ & 18 & $(60.0)$ & 11 & $(36.7)$ & 1 & $(3.3)$ \\
\hline
\end{tabular}

「集団上位者」を含采ぬ Vp 3 名と成人 1 名, 計 4 名 で自由遊びをやり，筆者が合図した時に，成人に次の 5 種類の「秩序破り行為」の内の 1 つをやらせを。

(a) 玩具の 1 人占め（(b) の玩具以外のすべて を 1 人占めにする).

(b) Vp の特に好现玩具の 1 人占め*（この玩 具以外は Vp に与㐫て和く).

(c) Vp の遊歔継続をさり気なく妨げる.

(d) Vp の持っている玩具を「それを頂戴」と いって取る.

(e) Vp の特に好む玩具を，(d) と同じやり方 で取る。

* Vp の特に好む玩具を見出す実験を別に行なった。 この結果「火を吐く機関車」が全ての Vp に最も 好まれていることが分った。
Table 5 Table 4 のろ5肾群・正常児群の百分率 の間の有意差検定

\begin{tabular}{c|c|c|c|c}
\hline & 1 & a & 東 & $=$ \\
\hline $\mathrm{a}$ & $\times$ & $\times$ & $\times$ & $\times$ \\
\hline $\mathrm{b}$ & $\times$ & 0 & $\times$ & 0 \\
\hline $\mathrm{c}$ & $\times$ & 0 & $\times$ & $\times$ \\
\hline $\mathrm{d}$ & $\times$ & 0 & $\times$ & 0 \\
\hline $\mathrm{e}$ & $\times$ & 0 & $\times$ & 0
\end{tabular}

……危険率 $5 \%$ 以内で有意.

$\times$ ……有意でない. 
返してやり，Vp の表情を観察した。この場合 4 名と も, 実験4の6名の者と同様な, 喜悦の表情を示した。 次実験 5 ・6 の結果に基づく考察を行なう・衣ず， 万 弓児群・正常児群を通じて，（イ）が全く現われないこ そに気付く。これは相手が成人であることに，大きな原 因が昰ると考光られる。(この成人は，日常 Vp に面識 ある人達である。）万弓児群には（口）も現われていな いが，正常児群にはかなり現われ，しか子(a)より(e) に近づくほど増光ている，そして (a) 以外の百分率は, 万う览群との間に有意差がある。（ハ）は両群の間に似 通った傾向が現われている。（二）は全般的に幾分ろろ 児に多いようである。

以上の結果から推察すると，ろら児が秩序破り行為」 に反擊したり抗議したりせずにいるように見えるときで る，岁るい慍表情に見光ていても，多くの場合心中に 不渍を持っているらしい（すずに実験 4 からも推測さ れることで, 実験 6 の結果もこれを支持する。）また両群 の（口）の百分率に相当の差があることは，正常児が心 理的な不満をコミュニケーションにより相手に伝え, フ ラストレーションによる心的緊張をある程度弱めたり， 合理的解決を図ったりすることが，ろ5览より多いこと 示唆する。

\section{実験 7,8 8 およ゙ 9 正常児のみを対象とす} る.

ろう児に（口）が少ないことと, 彼らのコミュニケーシ ョン能力の障害との間に, 関連があるか否かを迫求し, またもしこのような関連があるのならこれについてさ らに具体的に究明することを目標とした．正常児達の間 のコミュニケーションを種々の方法で制限し, コミュニ ケーション能力の点では, ろう児との差をなるべく少な くして、ろう児群との比較考察を行なった。

る台ろん一時的泟常児のコミュニケーションを制限 してみても，万弓児に比しての正常児の, 全人的機制の 相違はどうすることもできない。しかしこのような制限 は岕って子，この種の「仮装実験」から可能な範囲で近 似的条件を求め, 問題究明への手がかりとすることる, ある程度は可能と考光る。

奏験 1-6 に使用した正常児群の内の 4 集団は，保育 期間を終了したので, 新たに正常児「集団上位者」を, 前 回と同じ方法で選出し，「集団上位者」 1 名，仲間 3 名， 計 4 名の新集団を 4 つ作り, 旧集団の残存したるのと合 せた 8 集団を用意した。「集団上位者」の男女比は $5: 3$ で、女子が 1 名增えている. 新集団は旧集団と同じ手続 きで選出したとはいえ, 保育終了の集団に比して,いろ いろな意味である程度異質的で岀るか子知れない。しか 乙新集団も，予備実験の Vp として使用してからこの実 験に使ったため，この実験開始の頃にはメンバーの位置 もほぼ固定して特り，この点では特に旧集団との差異は
なかったと考える。

さらにこの 8 集団とは別に，「集団上位者」を含まな い3人の集団を 24 作った.この Vp の一部分は前の 8 集団のメンバーと重複している. 実験種目以次の 2 種類 そ予定した。

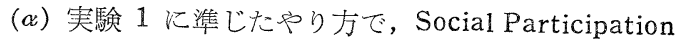
Scale の平均点を求める. Vp 以「集団上位者」を含む 8 集団の方を使用.

（B）実験 5 に準じ, 成人に実験 5 (a) (b) (c) (d) (e) の行為をやらせ, Vp の反応を観察する.Vp は 3 人から成る 24 集団の方を使用. 1 集団中直接に観察の 対象になるのは，1名だけとする。

実 験 $7 \mathrm{Vp}$ に発語を禁じ, 黙って遊ばせる。こ の実験は Vp に不自然な感じを与えたらしく, 多くの $\mathrm{Vp}$ が筆者に何故このようなことをするのか質問した。 しかも何回か発語を禁じても徹底せず，大部分の集団で は発語が行なわれてしまった。そのためこの実験は, 目 的に副わないと判断し中止した。（( $\alpha)$ のデーターを少 し集めただけで，( $\beta$ ）は全く行なわなかった。）

実験 $8 \mathrm{Vp}$ に耳栓をして遊ばせる。（恩地式防 音プラグ使用.）実験開始前に Vp の装用状態を1人ず つ調べ，完全に装用させた。しかしこの装置の音量減衰 能力は, 本実験の目的を果すには不充分であった。すな わち Vpは, 多少大きな声で話せば, ほとんど自由にコ ミニニケートできた・そのためこの実験は，目的に副わ ないと判断し中止した。（( $\alpha)$ のデーターを少し集めた の征)

実験 9 実験室内で Vp 間の会話を核とんど困 難にする音量にして、レコードをかける。耳のそばで話 しても話の内容は充分伝わらない程度の, マスキング効 果をむげた。一部のVp から不審の質問を受けたが，そ の際は筆者が好きでレコードを聞いているのだと答え， 真の意図をかくした。しかしVpに心る程度不自然な感 じを与えることは，避师られなかったと思う。結果を Table $6 \cdot 7 \cdot 8$ に示す.

Table 6 実験 $9(\alpha)$ の結果

\begin{tabular}{c|c|c} 
& 前 半 & 後 半 \\
\hline $\mathrm{AV}$. & -1.0 & +0.2 \\
\hline $\mathrm{SD}$ & 0.90 & 1.00
\end{tabular}

平均の差の検定 $: \bigcirc \cdots \cdots .$. 危険䘘 $5 \%$ 以内で有意. $\times \cdots \cdots$ 有意でない。

前半: 後半 $\bigcirc$, 前半: Table 1 万弓坚群の前半 $x$, 前半: Table 1 正常児群の前半 $\bigcirc$, 後半: Table 1 万5 览群の後半 $\times$, 後半: Table 1 正常児群の後半 $x$. 
Table 7 実験 $9(\beta)$ の結果

\begin{tabular}{|c|c|c|c|c|c|c|c|c|}
\hline 区 & \multicolumn{2}{|c|}{ (イ) } & \multicolumn{2}{|c|}{ (ㅁ) } & \multicolumn{2}{|c|}{$($ (八) } & \multicolumn{2}{|c|}{$(=)$} \\
\hline & 数 & $\%$ & 数 & $\%$ & 数 & $\%$ & 数 & $\%$ \\
\hline a & 0 & (0) & 0 & $(0)$ & 10 & $(41.7)$ & 14 & (58.3) \\
\hline b & 0 & $(0)$ & 0 & (0) & 9 & $(37.5)$ & 15 & $(62.5)$ \\
\hline c & 0 & (0) & 2 & (8.3) & 13 & $(54.2)$ & 9 & $(37.5)$ \\
\hline d & 0 & (0) & 1 & $(4.2)$ & 12 & $(50.0)$ & 11 & $(45.8)$ \\
\hline $\mathrm{e}$ & 0 & (0) & 4 & (16.7) & 12 & $(50.0)$ & 8 & (33.3) \\
\hline
\end{tabular}

Table 8 Table 7 の百分率と Table 4 のろ5児 群・正常児群の百分率の間の差の検定

\begin{tabular}{|c|c|c|c|c|c|}
\hline & & (イ) & (口) & $($ (八) & $(=)$ \\
\hline 対 & $\mathrm{a}$ & $x$ & $x$ & 0 & 0 \\
\hline ろ & b & $x$ & $x$ & 0 & $\bigcirc$ \\
\hline 5 & $\mathrm{c}$ & $x$ & $x$ & 0 & 0 \\
\hline 児 & $d$ & $x$ & $x$ & 0 & 0 \\
\hline 群 & $\mathrm{e}$ & $x$ & $x$ & $x$ & $x$ \\
\hline 対 & $\mathrm{a}$ & $x$ & $x$ & $x$ & $x$ \\
\hline 正 & b & $x$ & 0 & $x$ & $x$ \\
\hline 常 & c & $x$ & $x$ & $x$ & $x$ \\
\hline 坚 & $\mathrm{d}$ & $x$ & 0 & $x$ & 0 \\
\hline 群 & $\mathrm{e}$ & $x$ & 0 & $x$ & 0 \\
\hline
\end{tabular}

まず $(\alpha)$ の結果について考察する.Tabie 6 に示し たこと以外に，自然観察で気づいた点は，彼らに手末权 が全く現われないことであった。（ろう児群のコミュニ ケーションの手段は，ほとえど手香数に限られている.） 前述のように正常児のコミュニケーションを制限して も，ろう児に比しての条件の決定的な差異が残されてい る.これらの「条件の差異」が，今回の正常児にろう児 のような手まねを出現させなかったるのと考える。この 「条件の差異」について，今回の実験は具体的に明らか にすることができない，正常児のそれとは随分違ってい る，ろう児の過去から現在に到る生活空間の中から, こ の問題を究明する手がかりをえたいと思う・な祘，Vp 達 には発語によるコミュニケーションも, 汪とんど現われ なかった・
次に表に示した結果について述べる.Table 6 では丰 験 1 の正常児群に比して, 後半の平均值は同じである が, 前半はより低い. Table 1 と比較すると, 今回のコ ミュニケーションを妨げられた正常巟は, 次の 2 つ点 で実験 1 のろう児と似て来たといえる。

（1）前半・後半の平均值が実験 1 の万5児群と 類似していること。

(2) 前半より後半の平均值が高いこと。

(1) は, 集団のまとまりの水準や遊びの程度が, 大体 ろろ児のレベルまで低下したことを示晙する。また (2) は，「集団上位者」がリーダーシップを示さずをしろ集 団の秩序を低下させていることを䀧示する・これ子なた ろろ児集団に見られた特色である。

以上を通観すると，コミュニケーションを妨害した実 験 $9(\alpha)$ に和いては, 正常児集団の示すいくつかの傾 向が，ろう児の場合と似て来たこが示されている。

次に実験 $9(\beta)$ について, Table 7 ・8 を参照にして 考察する・（イ）は実験 5 の場合之同様，1回子現われ ていない（口）は実験 5 の正常児の場合よりも，全般 に百分率が低下している，そしてろう児群に百分率が近 くなり，ろう児群との間に (a)一(e)のどのケースに耑 いても有意差がない（ろろ児のように（口）が全く無い ようにはならなかったが。）(口）の面でろう児群に, 性 格が似て来たといえるで女ろう。

（父について見ると，この面ではろう児群に似て来 ないで，正常児本来の傾向を保持しているようである。 しかし前の実験 4 の結果から考えると, 万ら罗が無表情 の場合でも, 大抵は心理的に不満感を持っているらし い. 正常児の場合は，普通の条件下に和いても，今回の よらなユミニニケーションを放げられた条件下に秥いて も, この不満感が表情に現われ易く, これに反しろ5児 では表情涀われ難いのではないかと想像される。

（二）は実験 5 のろ弓児に傾向が幾らか似て来て, 無 表情の場合がやや多くなっている.この結果は, 万ら児 のコミュニケーションの障害が, 彼らに(二)を多くする 1 つの原因で岕ることを示唆している。しかし「コミュ ニケーションの不便さ」と「镩表情さ」との有機的連関 については，充分に説明できない現状にある。

\section{IV 考察のまとめ}

今回の幾種類かの実験は, 最初の実験 $1 \cdot 2$ で示晙さ れた，ろら児群「集団上位者」の，「秩序破り的性格に ついて考察することを目的とした。予備実験によって (6)，「体力」がこの種の「秩序破り」の主要原因でない ことが，結論づけられた。実験 3 一6によって，正常児 は「秩序破り」の行為に対して, 言葉や表情でしばしば 抵抗することが分った・このことは集団の上位に心る者 であっても，むまりに自己中心的な意図を通とうとした 
り、しばしば秩序を破ったりすることを控えざるを得な いような, 社会的雾团気を形成させるように㗢くである

了・仲間の抵抗を受けずに集団上位に上るためには, 㫣 る程度のリーダーシップを示すことが, 要求されている のであろう。

これに反し、万ら児群には「，秩序破り」に対するこの 種の抵抗が，㐫まり現わ机ないらしい。実験 4 ・6 の 結果から推察すると, 大抵の者は「秩序破り」に対して 心理的に不満感を持つょうであるが，多くは無表情で 「秩序破り」を見送ってしまう。このようなことは，ろ 了児群の社会的雾囲気を, 「秩序破壞者」が発生し易い るのとし，「集団上位者」の「秩序破り」を增加させる ように㗢くのではないだらうか。

上の考察からさらに一歩進んで考光ると, 万万児群と 正常児群では,「集団上位者」になるための必要条件が, やや異なっているのではないかと思われる・正常児群で は「集団上位者」になれないルールを無視する児童が， らう児群では上位に岀るように思光る。しかしこの想像 の当否について，具体的に論じるためのデーターは，ま だ獲得していない。

実験 9 の結果から推察すると, 万ろ児が「秩序破り」 の行為にあるり抵抗できない大きな理由は, 彼らのコ ミュニケーション能力の久陷にあるらしい，心理的不満 感を相手に伝光る手段が限定されているため, 多くの場 合意志を表明せず沉終るのではないかと考光る。

〔附記〕本稿で「ろう」として报ったのは，文部 省判別基準（8）の「ろ5」「高度難㯖」の者で峁る。
なお，御助力を賜わった村阔千鶴子氏に，感謝の意を表 する。

\section{文献}

1) Stogdill, R. M. Leadership, membership and organization. In Cartwright, D. et al. (Ed.), Group dynamics. New York: Row, Peterson \& Co., 1953, Pp. 39-51.

2) Cattell, R.B. New concepts for measuring leadership in terms of group syntality. In Cartwright, D., et al. (Ed.), Group dynamics. New York: Row, Peterson \& Co., 1953, Pp. 14-28.

3) Gibb, C. The principles and traits of leadership. J. abnorm. soc. Psychol., 1947, 42, 267-284.

4) Redl, F. Group emotion and leadership. Psychiatry, 1942, 5, 573-596.

5) 心理学辞典, 平凡社 $1957,273$.

6）小川再治 万5幼児遊践集団の锶察，児意心理 と精神衛生, 1956, 29, 24-28.

7) Parten, M., et al. Social behavior of preschool children. In Barker, R. G., et al. (Ed.) Child behavior and development. New York: McGraw-Hill Co., 1943, Pp. 509-526.

8）文部省 特殊览童判別基準とその解説，1953， 42. 1958. 7. 19. 受稿

\title{
SOME CHARACTERISTICS OF THE "BULLIES" AMONG THE DEAF CHILDREN OF FIVE AND SIX YEARS OF AGE
}

\author{
Saiji OGawa \\ Tokyo University of Education
}

\begin{abstract}
In the preparatory experiments, the author found that the physical strength of the deaf and hearing bullies over their fellows did not differ greatly and that the deaf bully was not always physically stronger than his fellows.

Experiments 1 and 2 were conducted during ten
\end{abstract}

minutes of free play. Control groups consisted of hearing children of the same age. Groups were formed each consisting of a bully and three fellows. During the first five minutes (period "a") all of the children in the group played together. At the end of the period " $\mathrm{a}$ " the bully was removed from the group, and the fellows continued to play during the following five minutes (period "b"). 
The author measured the degree of social participation in periods "a" and "b" with Parten's Social Participation Scale. In period "a" the experimental group had a lower degree of social participation than in period "b". The control group showed the opposite tendency in comparison with the experimental group. Namely, in periods "a" they had a higher degree of social participation than in periods "b".

From these results, the author supposed that the bullies of the deaf group have somewhat more destructive tendencies compared with the bullies of the hearing group.

In Experiments 3, 4, 5 and 6 the author observed the reactions of the fellows against the destructive acts of the bullies. Though the hearing fellows often showed the verbal objections against the bullies, the deaf fellows never manifested such objections, and often submitted themselves to the bullying expressionlessly.

Experiments 7 and 8 failed.

In Experiment 9, the author used the hearing groups only. He put a record on the gramophone and played it very loudly and disturbed their mutua communications during their free play, and he measured the degree of social participation of their groups. The results of this experiment were fairly similar to the results of the experimental groups in Experiments 1-6.

Based on such results, the author supposed that the destructiveness of the deaf bullies resulted largely from the inferior ability for communicatio $\mathbf{n}$, among deaf children. 